\title{
Management of care to chronic conditions in the rural under the coordination of nurses
}

\section{Tamires Viviane Aparecida Diehla \\ Felipe Rodrigues Garcia de Souza ${ }^{b}$ \\ Vilma Constancia Fioravante dos Santos ${ }^{c}$ \\ Deise Lisboa Riquinho ${ }^{d}$ \\ Adriana Roese Ramos ${ }^{\mathrm{d}}$}

How to cite this article: Diehl TVA, Souza FRG, Santos VCF, Riquinho DL, Ramos AR. Management of care to chronic conditions in the rural under the coordination of nurses. Rev Gaúcha Enferm. 2021;42:e20200298 doi: https://doi.org/10.1590/19831447.2021.20200298 a Faculdades Integradas de Taquara (FACCAT), Curso de Enfermagem. Taquara, Rio Grande do Sul, Brasil.

- Pesquisador Autônomo. Gravataí, Rio Grande do Sul, Brasil.

Secretaria Municipal de Saúde de Porto Alegre (SMS). Porto Alegre, Rio Grande do Sul, Brasil.

dUniversidade Federal do Rio Grande do Sul (UFRGS), Escola de Enfermagem. Porto Alegre, Rio Grande do Sul, Brasil.

\section{ABSTRACT}

Objective: To analyze the perspective of Nurses Coordinators of Family Health Teams on the management of care for people with chronic illness in rural areas.

Method: Qualitative approach exploratory study, carried out in a Health Region of Rio Grande do Sul, together with the Nurses in charge of the Units, between 2014 and 2015. The sample included seven participants. Data analysis was driven by thematic categorization and using NVIVO software.

Results: The thematic categories identified were: The administrative political organization of health care; The pluralities of rural impose specifics on care management and Strategies for management of care in the rural areas.

Final considerations: We pointed out elements of care management that are related not only to individual care, but also elements related to broader dimensions of health care, such as the social and political relationships that tension over the territories and that have implications to clinical practice.

Keywords: Rural health. Public health nursing. Health management. Comprehensive health care.

\section{RESUMO}

Objetivo: Analisar a perspectiva de Enfermeiras Coordenadoras de Equipes de Saúde da Família sobre a gestão do cuidado às pessoas em adoecimento crônico no rural.

Método: Estudo exploratório de abordagem qualitativa, realizado em uma Região de Saúde do Rio Grande do Sul, junto às Enfermeiras em cargo de Coordenação das Unidades de Saúde da Família, entre 2014 e 2015. A amostra foi constituída por sete participantes. A análise dos dados se deu por análise de conteúdo do tipo temática, com apoio do software NVIV0.

Resultados: Categorias temáticas identificadas: A organização político-administrativa da atenção em saúde; As pluralidades do Rural impondo Especificidades à Gestão do Cuidado e Estratégias para a gestão do cuidado no rural.

Considerações finais: Apontam-se elementos da gestão do cuidado que estão relacionados não só ao atendimento individual, mas também elementos ligados a dimensões mais amplas da atenção em saúde, como as relações sociais e políticas que tensionam os territórios e que têm implicações à prática clínica.

Palavras-chave: Saúde da população rural. Enfermagem em saúde pública. Gestão em saúde. Atenção integral à saúde.

\section{RESUMEN}

Objetivo: Analizar la perspectiva de las Enfermeras Coordinadoras de los Equipos de Salud de la Familia sobre la gestión de la atención a las personas con enfermedades crónicas en el rural.

Método: Estudio exploratorio de abordaje cualitativo, realizado en una Región de Salud de Rio Grande do Sul junto a las Enfermeras en cargo de Coordinación de las Unidades de Salud de la Familia, entre 2014 y 2015, la muestra consistió en siete participantes. El análisis de datos se realizó mediante análisis de contenido temático, con soporte del software NVIVO.

Resultados: Categorías temáticas identificadas: La organización política administrativa de la atención en salud; Las pluralidades del rural imponiendo especificidades a la gestión del cuidado y Estrategias para la gestión del cuidado en el campo.

Consideraciones finales: Se apuntan elementos de la gestión del cuidado que están relacionados no sólo a la atención individual, sino también elementos vinculados a dimensiones más amplias de la atención en salud.

Palabras clave: Salud rural. Enfermería en salud pública. Gestión en salud. Atención integral de salud. 


\section{口INTRODUCTION}

Nursing in rural communities has made important advancements and requires special attention in this field of knowledge. In a complex and interdisciplinary manner, it has constructed a relevant theoretical and conceptual corpus that supports care practices ${ }^{(1-2)}$. This scenario calls for reflection on the need to (re)construct the nursing practices in primary health care $(\mathrm{PHC})$ in order to expand the role of nurses and guarantee centrality in the care of individuals, families, and communities ${ }^{(3)}$.

In this regard, studying rural areas beyond their economic and productive relevance may improve access to health services and shed light on the specificities of this territory, as well as the action of public policies ${ }^{(4-5)}$. The populations living in rural areas still have difficulties ensuring their full rights, so efforts should be made to give visibility to these communities and discuss how to guarantee effective social protection and forms of sustainable development ${ }^{(6)}$.

The Brazilian public health system seeks to provide health care for rural communities by proposing specific policies for this territory and implementing strategies that facilitate access to health services and qualify case management based on PHC and meeting the care needs and demands of rural and forest populations ${ }^{(4-7)}$. The structuring of health care from $\mathrm{PHC}$ has better results in relation to the use of resources and impacts on the population's health. These elements are especially relevant in relation to chronic conditions, which urge the need to overcome fragmented care and make political-institutional improvements in the universal coverage systems ${ }^{(8-9)}$. In this sense, the term chronic conditions in health care resembles that of chronic non-communicable diseases but instigates and challenges debates that go beyond the understanding of diseases as being related to the individual body and refers to health conditions that require continuous and integrated actions on the part of the state and society, with greater focus on the individuality of the health-disease process ${ }^{(8)}$.

Health care management is an important element for health managers and workers to create common goals, share and transfer knowledge from the theoretical field to the care practice, especially care, considering that care management is centered on the production of comprehensive care with quality and safety aimed at the health needs of people and populations ${ }^{(10-11)}$. This is an increasingly pressing need in the field of care, especially when conditions that challenge health systems are prevalent, such as chronic conditions, which require continuous, proactive, and integrated responses and actions from the care system, health workers, and users for their effective, efficient, and quality contro( ${ }^{(8)}$. In this regard, chronic illness is recognized as a serious public health problem worldwide; in Brazil, there are additional structural and budgetary difficulties, as well as persistent inequities in health care (12-13). $^{(1)}$

Given the constant (de)legitimization of suffering imposed by chronic illness, care management strategies are urgently needed to articulate the different areas involved in the user care process and ensure centrality to users in care $\mathrm{c}^{(8,10,14)}$. Chronic illness can make life in rural areas more complex and problematic, mainly due to the need to articulate care in a network in an organized and orderly manner ${ }^{(5)}$. Therefore, it is essential to better understand the users of a system and subsequently break from the supply-based management, which is so characteristic of fragmented systems, and manage care based on health care needs ${ }^{(8)}$.

Reorganization of the care model and internalization of health services, especially in rural areas, are relevant topics for the debate on social protection in Brazil, especially regarding public health policies, given the greater vulnerability of these populations to illness ${ }^{(4-6,15)}$. Moreover, the rural dimensions of Brazil must be acknowledged to intervene in the health-disease process within PHC of the Unified Health System (SUS, or Sistema Único de Saúde, in Portuguese), chiefly regarding the singularities and specific characteristics that condition the organization of health services and practices for rural communities ${ }^{(16)}$.

Based on the perspective that nurses provide care and manage health service ${ }^{(3)}$, in practice, these professionals should focus on providing people-centered clinical care in dealing with families and individuals in different life cycles and construction of identities, as well as adapt the organization of health care services to the diversity of the area in which they are located. That said, and considering the relevance of studying the practice areas of nurses and the different public policy scenarios, this study was conducted in a rural health care region in southern Brazil. This study was guided by the following research question: How does care management occur for users with chronic conditions in rural areas? Therefore, the aim of this study was to analyze the perspective of coordinating nurses in health care teams on the care management of chronically ill individuals in rural areas. 


\section{METHOD}

This is a qualitative, exploratory, and descriptive study, conducted according to the methodological guidelines of Minayo ${ }^{(17)}$. The empirical area of the study was one of the health regions of the state of Rio Grande do Sul, southern Brazil. This region is composed of the six municipalities of Alvorada, Cachoeirinha, Glorinha, Gravataí, Porto Alegre, and Viamão. Within this scope, in the organization of health care in rural areas, two municipalities were included, municipality $A$ and $B$, as they are the only ones that provide care in rural areas. Although the other municipalities include rural areas, they do not provide a rural team format. The names of the municipalities were not disclosed due to ethical issues. Municipality A and B are $23 \mathrm{Km}$ and $10 \mathrm{Km}$ from the city of Porto Alegre, respectively.

The sample was selected intentionally and the study participants were coordinating nurses of the family health units located in the rural empirical area, four from municipality $A$ and three from municipality B. The inclusion criteria were being a nurse and working as a coordinator of the family health units (FHU) in rural communities. The exclusion criteria were working in this position for less than six months, to guarantee more precise information on the daily routine at the unit, and rescheduled interview, due to the distance traveled by the researchers to the rural health units. Thus, the sample consisted of seven coordinating nurses from rural FHU in the empirical area. There was no loss of sample since all the coordinating nurses agreed to participate in the research. Furthermore, it should be noted that not all teams had a coordinating nurse. In the period of empirical data generation, thirteen health teams were operating in the empirical area, divided among the seven health units, that is, in some services there was more than one team operating in the same health unit. The teams were distributed as follows: municipality A consisted of ten teams in five FHU, while municipality $B$ consisted of three teams in two health care units.

Data were collected using a semi-structured interview script that contained three axes: I - Professional actions and practices; II - Workflow in the care of chronically ill patients; and III - Health care management. The questions contained in the axes sought to explore approaches to users in the health unit and territory; workflow that favored the team reception of users and team accountability for rural users; team practices when forming bonds with users and their families; outlook of the family reality and social environment for proposing care; identification of social network integration mechanisms; and positive and negative factors when relating to chronically ill rural users. At the moment of data generation, the term chronic diseases was used, while the term chronic conditions was adopted for the debate proposed here, according to broader reflections on the experience of chronic illness, such as those of researcher Eugenio Vilaça Mendes ${ }^{(8)}$.

To conduct the interviews, the coordinating nurses were contacted by telephone to schedule the interview, between 2014 and 2015. All interviews were conducted at their workplace, as requested by the respondents, and lasted 40 minutes on average. The interviews were recorded on digital audio equipment, transcribed in full, and then double-checked by the researchers. After conducting each of the interviews, field notes were recorded containing brief descriptions of the visited health unit and information on the distances traveled by the interviewers to support other incursions into the empirical field. To protect the identity of the participants, their statements were coded as Coordinating Nurse in Rural 1 (CNR1) and so on, according to the order of presentation of the empirical data. The empirical categories were identified using NVIVO 9 software (QSR International, Massachusetts, USA).

The data were processed using the framework theme/ category-based content analysis, as proposed by Minayo (17), consisting of the following steps: pre-analysis, with reconsideration of the guiding questions and initial study objectives; exploration of the material by classifying the statements to reach core understanding of the text, immediately followed by the establishment of categories; treatment of results, with highlighting of most relevant information to understand the study object; and interpretation, with interpretive effort to list all references and frameworks adopted by the researchers with the empirical reality presented to them, thus better understanding and interpreting what has described by the respondents. Data saturation was achieved when the interviews did not bring new information, which was identified when the data provided by the study sample was explored. The thematic categories were organized according to the collective health references, namely bond, reception, care management, health care networks, and health mediation to support discussion of the categories.

This study was approved by the research commission of the Escola de Enfermagem da Universidade Federal do Rio Grande do Sul (UFRGS), by the ethics committees of UFRGS, and by the municipal health department of Porto Alegre (Secretaria Municipal de Saúde de Porto Alegre - SMS/ PMPA), respectively under opinion numbers 708.357/2014 and 885.916/2014. Informed consent was obtained from all the study participants. In all stages of research, the ethical precepts of the current legislation on research with human beings were respected. 
During the detailing of the research method, the criteria defined in the consolidated criteria for reporting qualitative research (COREQ) were followed to support the rigor and credibility of the research and describe factors such as research team and reflexivity, study design, and data analysis.

\section{RESULTS}

The categories identified from results analysis were the following: The political-administrative organization of health care; The pluralities of rural communities imposing specificities for care management; and Care management strategies in rural areas. These categories will be presented throughout the results section and discussed according to the theoretical and conceptual framework of collective health.

\section{The political-administrative organization of health care}

In the scenario under study, the teams work in an extensive geographical area that requires different administrative organization logistics than used in urban areas, which hinders the establishment of home care routines. The distances to rural areas force coordinating nurses to adopt reference points that make sense to these communities, such as marking distances from bus stops and specific locations where the team meets the users.

[...] our coverage area ranges from stop 109 to stop 79... so...quite large, and our community worker registration area is $1 \mathrm{~km}$ inwards, starting from RS inland...sideways, both to the left and right, because if not, we cannot do the visits and monthly follow-up of users if it is more than that. (CNRO1)

The coordinating nurses mentioned that the teams have not been able to plan their geographical regions due to the size of the assigned area and to the constant migration of users, which causes the movement of people between neighborhoods, territories, and the administrative division of municipalities itself, which is the target of constant political disputes. This issue impacts the management of processes required to territorialize and organize the assistance flow of users. One of the coordinators reported that, due to the designing of territories, the team no longer has community health workers (CHW) to assist users in a given area, even if they are linked to the team and have historically received care in the health service. All efforts to maintain the commitment to provide care to users in this scenario were triggered by media reports of the situation.
[...] So I no longer have a health worker there, I no longer make visits there and we should not even be assisting people there anymore, they should be going to the unit of [name of the neighboring municipality]. They even closed the school out of there, everything, right? But there were a lot of repercussions, as people were registered here, they had a bond here. The media was here, the secretary, and then they issued another statement: for us to provide care as free demand, without registering the families. (CNRO2)

When addressing the care management process, the coordinating nurses mentioned broader aspects of their work, such as employment bonds. The workers perform similar functions with different employment bonds and salaries between the employees and contractors, which has affected interpersonal relations and accountability for work tasks in the daily routine of health services. Below, a statement of one of the health service coordinators:

[...] we are hired and, at first, it was quite complicated because people notice the differences in payroll, amount of work, and the salary we get; ours is higher...and then we had a conversation, a very adult conversation about it, we are not to blame for anything. [...] it's not a problem I have with you... it's a problem further up... [...] (CNRO1)

One of the coordinators mentioned the difficulty they face in organizing care due to the inadequate physical structure, which forces them to look for alternatives to be able to provide care to users. However, the respondent believes users should not be subjected to inadequate conditions due to the lack of physical structure of the health unit.

Here at the unit, we have physical space problems; me and the other nurse have to share consultation rooms because there are none for two nurses. Is that a problem? Yes, it is a problem when I have a patient and so does she. If I see my patient in the consultation room, she has to see her patient in the corridor. It is not dignified for users to have appointments in the corridor, where their lives are exposed, their problems exposed, because everyone is walking up and down, passing. They have no privacy. But, I can't simply pretend I don't care [...] (NCRO3)

Another factor that pervades care management in rural areas is the stigma that was still perceived by the respondents regarding the need to ensure care is as organized 
as in urban areas. In one of the municipalities, it was also reported that formalized care is being implemented. One of the coordinators said that she was the first to assume the position of unit coordinator. Previously, the perception of care to users was of abandonment and little attention given by local authorities to workflow in the health service.

\section{[...] this unit has always been very abandoned [...].it was not like this before; people came here to get a number for their appointment, without proper reception, they paid someone to stand in line at dawn, then the physician sometimes did not come... other times, they would wait 10 hours... So, there were no specific activities; I was a technician on my own doing what I could and the phy- sician would come here from time to time...that's how it was. [...] (CNRO4)}

Moreover, some coordinating nurses of both municipalities stated that health services still have structural deficiencies to provide care and ensure accessibility to users.

\section{[...] since this unit was inaugurated, it has been adapted, it was an adapted house, some rooms were transformed into consultation rooms...butevery unitneeds renovations [...] there are termites in the doctor's offices, in all three, in mine, in the physician's, in the dentist's, the meeting room and the screening room, and when it rains hard, there are drips in the dressing room. [...] There was the PMAQ grant, we are waiting... [...] (NCRO5)}

The political-administrative organization of health care at local level, especially in rural areas, presents different inequities concerning how care is organized. Furthermore, it seems to overlap with the activities of the coordinating nurses who, together with the teams, seek to cope with the various challenges in the care of rural users.

\section{The pluralities of rural communities impose specificities for care management}

The role of coordinating nurses in the management of teamwork processes is challenged by particularities imposed by the rural environment. One of the coordinating nurses pointed out that, because users are physically distant from the health unit, they must travel great distances to receive care, which should be considered when proposing health worker schedules and the requirement that they be understanding and flexible.
[...] to organize the service, we have to think, "No, he is from this or that location. To be honest, he will never get there at the time I need him to get there." [...] I have to remember that the patient lives in a certain plain and, if he has no wagon, he depends on the bus, and the bus only goes there at one specific time of the day. If not, he will have to walk five kilometers to the roadway to catch another bus here. [...] (CNRO2)

In the effort to adapt the work process, the health services have vehicles provided by the municipal health departments that enable them to move within the territory and give them the opportunity to provide care in areas that do not have CHW. These vehicles are an important resource for the success of health services, given that this reality emerged in municipalities with still undiscovered areas without reference teams.

We have a part-time car every 15 days for home visits... [...] we give preference to people outside the area, to people who are outside the area of coverage, because those who are inside the area are already being followed-up, right!? They are being visited...perhaps not as often as we would like, but they are being visited by the community workers. [...] (NCRO1)

Because of the structural deficiencies perceived by the nurses, the nursing teams are constantly pressuring local authorities to expand resources and better qualify health services.

[...] then I told the department of health people that it would be important for us to have another community health worker. They say that the number is appropriate, but they recognize that, because it is a rural area, distances have to be covered to make home visits... [...] (NCRO5)

Care management in rural areas was also impacted by elements beyond the control of health workers, such as climate. In rainy seasons, it is impossible to access certain localities, which isolates residents and even diminishes their frequency in the health service.

[...] If it rains, I have no way of going to certain places because we cannot pass either by car or on foot. People are actually isolated. Here, it is very difficult, even inside Morungava, to come to the unit. (CNRO2) 
Regarding transport and access to health services, users have difficulty getting to the units either because they do not have a vehicle or public transport near their homes or the health unit. To solve this problem, users seek assistance outside their territory due to feasibility, as highlighted by one of the respondents.

[...] Here for the rural areas, it can be complicated; lots of patients do not have a car, they rely on buses, bus schedules are complicated (...) they have to go down for a bit and walk or depend on lifts; sometimes, the patient is not well during the day but family members will only get home with the car at night, so they get sick during the day waiting for the family member to get home to take them. (CNRO6)

The realities of health care in rural areas presented health workers with an important burden, as users are almost solely dependent on the teams that work in this territory, and some make sporadic trips outside rural areas. The fact that these health workers were the exclusive representatives of the state in the territory and the vulnerability experienced in certain localities were a constant strain on their performance.

It creates an overload and causes distress at the same time. We are the only ones... the assistance I told you about, the needs, it is endless, and then what happens? Most of the issues are social but they have certainly already compromised the body in some way. [...] Basically, social issues and people want medicine for them: medicalize social issues. (CNRO2)

The coordinating nurses highlighted difficulties in receiving the necessary support from the health care network (RAS or Rede de Atenção à Saúde, in Portuguese) to meet the demands of users. This was due to the difficulties in establishing communication with the other services of the urban area of the municipalities and facilitate the flow of care. Moreover, they stated that the form of service to users is bureaucratized and hampered by the logic of referrals that requires users to travel constantly from rural to urban areas, as well as by the network's installed capacity to account for the service.

[...] when patients need the network, they are having difficulties accessing the network. Patients might even try to see a specialist, you refer them, the bureaucracy they have to go through access that specialist. [...] but you never see this in your daily routine, you know it exists, but you cannot see you getting it... the nutritionist went on leave and they already sent a memo saying to refer only the most serious cases for the nutritionist to be able to the workload, the one who is still there. [...] (CNRO7)

The nurses reported situations in which other workers of the health care network have difficulties understanding the specificities of rural communities and do not adapt their protocols or mode of care.

[...] the SAMU [ambulance service] does not come here, the municipality ambulance does not enter the alleys, they stop here on the RS [highway] waiting for the patient to arrive. [...] until they actually get here and take the person to the hospital...it was a long time, right!? More than 2 hours for sure. [...] (CNRO4)

The pluralities of rural areas impose specificities on care management and these elements demand even more from the coordinating nurses. In many territories, the health teams are the only resources available to users that represent the state. The efforts of these workers to adapt work processes to the constant obstacles that arise, to the distances, climate, transport difficulties, work overload, and network support reveal their persistence in the pursuit of better conditions from the local administration.

\section{Care management strategies in rural areas.}

Care for the chronically ill in rural areas is managed using strategies such as team meetings, albeit with some resistance in maintaining these events. However, it is acknowledged by the coordinating nurses as a device to discuss and plan the care provided by the teams and the management of the cases.

They even thought of removing these moments, but the team meetings were maintained. Because it is chaos at other times and we are busy with activities, consultations, assistance, and we cannot sit and talk with the team, so it is super important as a means to organize the way we work here. [...] (CNRO5)

In some locations, there was community radio, which facilitated communication between the team and people living in locations far from the FHS and the divulging of coexistence groups. Moreover, the therapeutic alliances between teams and communities trigger the emancipation of broader processes in the organization of health promotion strategies. One of the coordinating nurses stated that the 
community radio was important to strengthen the health education group for users with diagnosed systemic arterial hypertension and diabetes mellitus.

We have the community radio, we ran the campaign ads, and we got a location. Before that, we started doing it here...very modestly, here in the kitchen... and then people started coming, 10...then 15...then 40, until we could not do it here anymore, we started...it started getting crowded here everywhere and we asked the community health workers to organize their work in the region and get a place, until we got the CTG in Morro Grande, at stop 95. We managed to get this place every Wednesday afternoon, every 15 days, for the HAS [systemic arterial hypertension] and DM [diabetes mellitus] groups.......] (CNRO1)

The group meets up at the mother's club, at school...the mental health group. The bond is really good. (CNRO8)

One of the coordinating nurses stated that, due to the work being done with the chronically ill people living in rural areas, based on assistance and group activities, they have been able to promote self-management among users in some localities. This was considered a strong point for the health care provided by the rural teams.

[...] "I have never been to the doctor, I do not need one"; we have a lot of people that still have this mentality, I managed to do it with assistance, when I started here, managed to make a lot of people stop looking for emergency care... [...] the group also helped a lot, HAS and DM. The people really love it, they go and have fun, talk and not everyone knows each other and among themselves, they want to form another group that is physical activity, they alone are working toward physical activity, so this group of HAS and DM is doing very well. (CNRO1)

Care management in rural areas has received relevant support from the CHW. In addition to forming a bond with the communities, it reported on routines at the unit, team schedules, and how to get and request care. This makes people feel closer to their unit and that the care can provide solutions.

\footnotetext{
$[. .$.$] The first thing is for the CHW to create a link between$ patients and the health unit, conduct active searches, promote care, prevention in whatever is needed... anyway... within their scope, right...they have a critical role. (CNRO4)
}

According to most of the coordinating nurses, this link serves as a care management tool since it facilitates recognition of the health needs of users and the negotiation of therapeutic project proposals. In the following statement, one of the coordinating nurses highlights the benefits of assistance and forming bonds or links by using the example of a medical colleague:

\section{[...] they like him very much and listen to what he says, it is an advantage to have this bond. For people to take care of themselves, they have to have that too...that...bond, no point coming and not looking into the person's eyes and just prescribing medication...it is not about that... there is a lot to be done. (CNRO4)}

Care for the chronically ill in rural areas in most of the services was related to the diagnosis of systemic arterial hypertension and diabetes mellitus due to the care strategies aimed at these diseases. However, there were reports of other important chronic illnesses in rural areas such as those related to mental health and obesity. The presented care management strategies were diverse but lacked the necessary standardization among the health units. Furthermore, the strategies that strengthen teamwork and bonding are the most widely reported, which is possibly related to the chronically ill who live in rural areas and confront different barriers to achieve the desired health care.

\section{DISCUSSION}

Rural care management is permeated by elements that involve the political and administrative organization of health care to users and the dynamism of the territory itself. The collected data reinforce the understanding that chronic illness requires joint efforts ${ }^{(5,8,13-14)}$ and rural care management entails constant tension between local specificities and the broader organization of the health system. Notably, a stigma still exists on the part of local authorities and urban workers in the provision of care to rural communities, and these conditions impose distancing and hinder access to health services ${ }^{(4-5)}$. This was most prominent when the coordinating nurses demanded the qualification of physical resources and teams or when they needed to refer users to other points of the health care network.

Insufficient physical resources and barriers to the transportation of users to other health units compromise the comprehensiveness of care and the guarantee of rights. Thus, the structure of health units must be qualified to enable interventions in social and environmental processes that 
are common to rural environments, such as the physical and social distances that still impair access of rural communities to health services, especially the chronically ill(4-5,9). These elements demand a critical and permanent discussion of the management of care for chronic conditions given the urgency to overcome the weaknesses pointed out by the respondents. Moreover, in the association between living in rural areas and the complexity of chronic conditions, more sensitivity and more proactive social responses are required on the part of the state and civil society.

Creating bonds and providing initial assistance are important tools for the management of care to the population; in rural areas, these factors become an even greater challenge given the distances and structural difficulties, such as insufficient public transport. In order to rethink the rural area as a space of care production, it is important to understand the dimensions of rural areas, including the need for public policies that meet the demands of these populations by guaranteeing access to essential goods and services for development and permanence, such as economic, social, and cultural conditions, thus giving visibility to the new emerging ruralities in the field ${ }^{(4-5,18)}$.

The study of care management with the coordinating nurses revealed that the plurality of rural areas is precisely what shines the spotlight on and triggers the field of health care to rethink the bureaucratization of care and the gap between traditional and academic knowledge. Considering that factors such as climate, geographical size, and the bureaucracy of the health care network regarding its many waiting lists, referral documents that need to be taken by users personally to the urban areas reveal the persistence of structural inequalities and stigma. In this regard, the power to cross-aggregate different devices and approaches in the care of the chronically ill emerges as a way of gaining access to subjectivities and, subsequently, establish a more articulated and sensitive format ${ }^{(5,15)}$. This process may lead to the production of qualified and dignified care in the individual and collective context by overcoming the barriers that prevent users from exercising their rights ${ }^{(6,15)}$.

As also pointed out by the coordinating nurses, it is relevant to discuss the involvement of health workers in activities in locations outside the health units, such as community centers, churches, and community radio stations. In rural areas, these activities contribute to the care of chronically ill patients by narrowing the gap between care and management of the professional practice since they simultaneously perform coordination activities at the units and clinical and educational activities adapted to rural communities. These activities highlight the complexity of rural nursing and of the nurses' work in $\mathrm{PHC}^{(1,3)}$. Furthermore, it is believed that, in some way, there is the re-signification of health practices and the effort to meet the polysemic concept of care management, ranging from the planning and organization of health services units aimed at management of the clinic to the establishment of principles for the elaboration of activities in this area ${ }^{(11,19)}$.

Nursing plays a central role in the coordination of primary care in rural areas since nurses work directly with the care demands of these users and provide care in its different modalities, such as nursing consultations, home visits, initial assistance, and educational activities in groups and for individuals. Moreover, the relevance of nurses in the care of chronically ill patients lies in working at the forefront of the fight for user rights together with their teams and proposing individual therapy projects that enhance knowledge and practices on a daily basis, based on scientific evidence and on advanced nursing practices, such as the request and the completion of certain tests and the autonomy to refer and counter refer users, with a focus on the community ${ }^{(1,3,4-5)}$. Discussion on issues related to chronic conditions ultimately include elements of the role of nurses as local mediators of the state when they provide materiality to public policies and health programs during the performance of their activities and act as agents of social health care production and as part of the social protection network of which the chronically ill are so lacking ${ }^{(4,8)}$.

The reflections raised herein highlight the need to train health workers who are more autonomous and critical of their work process, who develop skills aimed at leadership in nursing, and who have specialized knowledge in this area of activity. Moreover, this could enable professionals to adapt and build knowledge and practices in rural nursing based on the needs and specificities of daily care ${ }^{(1,16)}$. Nursing professionals would also become aware of the iniquities to which the rural and forest communities are exposed, which not only involve lack of access to material goods such as television, refrigerator, and electricity but to observance of their rights and full exercise of citizenship. These factors lead to situations of vulnerability based on the lack of opportunities and poverty due to lack of formal jobs, access to adequate food, and decent housing, education, basic sanitation, and health services ${ }^{(7)}$. In this context, issues related to the social construction of the identity of individuals in rural areas can be highlighted, with their productive specificities, relationship with the land, and construction of the feminine and masculine ${ }^{(5)}$. 
The discussion proposed in this study brings to light the need for professionals working in rural areas to understand the historicity of the constitution of rural territories and the context in which they are inserted, in the sense of undertaking to manage care for the chronically ill while recognizing the diversity of itineraries that are woven in these territories. Without neglecting some particularities experienced in the nursing practice in rural areas, it is possible to further highlight daily challenges, such as socioeconomic diversity and epidemiological profiles, difficulties in accessing health services, and the social isolation caused by lack of access to certain goods and services such as the internet and public transport, as well as the climate ${ }^{(6,20)}$.

\section{GINAL CONSIDERATIONS}

The analysis of care management for chronically ill individuals in rural areas provided insight into the weaknesses related to the political-administrative organization of health care and emphasize the importance of planning strategies to cope with the different challenges imposed by rural areas listed in the results - and that hinder the organization of flows, process management, and care in these areas. Furthermore, this study revealed that the coordinating nurses who work in rural areas face difficulties imposed by the environment and the structure of this environment. Care management aimed at chronic conditions in rural areas occurs with the users of this territory and the employment of strategies and tools that enhance care and help overcome obstacles such as organize a home care routine that is different from that of urban areas; create alternatives to the inadequate physical structure (sharing consultation rooms, for example); struggle with the local government to give visibility to the problem of care in rural areas, expand the supply of resources to qualify services, and plan schedules (consultations, group activities), taking into account the distances traveled by users; and other factors that demonstrate the persistence of these professionals in the pursuit of qualified care management for rural populations.

Care management in rural areas from the perspective of the coordinating nurses of the family health teams involves work processes in this territory permeated by the inherent pluralities of this environment, which impose specificities to the care and daily routine of the teams, and mobilizes nurses in the search for improvements in structure, the bureaucratization of access, and health care network with the local government. This study provided important reflections that contribute to the construction of knowledge in rural nursing and care for the chronically ill. The possibility of listing the obstacles and potentialities of care management in this environment supports the planning of nurses' work in rural areas.

Despite advancements, the presented scenario reveals the need to discuss strategies that facilitate access of rural users to health teams and establish devices that guarantee horizontal and care-based relationships. This study also encourages discussion on elements of care management that are related both to individual care and broader dimensions of health care, such as social and political relations that cause strain in these territories and have implications for the clinical practice, all of which are relevant in the professional practice of nurses.

This study highlights the need for nursing education that provides workers with skills and abilities for clinical work in the care of chronically ill individuals in rural areas and for the implementation of public actions that are aligned with the specificities of this territory. The expected coherence of care management permeates the dynamism of the territory in question and the necessary equity of the care provided, aiming to ensure the right to health care and the exercise of citizenship through health. Nurses employ different strategies for the management of care in rural areas, such as team meetings, including for case management, use of community radio to divulge information from the health units and health promotion activities to the community, groups, assistance and bonding of the team with users, engagement of the $\mathrm{CHW}$, and strengthening of teamwork. Moreover, it should be noted that care management for the chronically ill in the most equanimous rural areas relates to the characteristics indicated above.

The specificities addressed here should be shared in academia, especially in the international scenario, as Brazil is still an eminently rural country in terms of both distances and number of people living in these geographical areas, which differs from other countries with smaller territories and which have already established, in a more structured way, access to health services. This study has some limitations, namely the use of a single research technique and interviews with coordinating nurses. Further studies should involve users in research that explores dimensions of care management such as co-responsibility for collective interests and the production of health care in rural areas. 


\section{REFERENCES}

1. Lima AR, Buss E, Ruiz MC, González JS, Heck RM. Rural nursing formation possibilities: integrative review. Acta Paul Enferm. 2019;32(1):113-9. doi: https:// doi.org/10.1590/1982-0194201900016

2. Hauenstein EJ, Glick DF, Kane C, Kulbok P, Barbero E, Cox K. A model to develop advanced practice nurses for rural practice. J Prof Nurs. 2014;30(6):463-73. doi: https://doi.org/10.1016/j.profnurs.2014.04.001

3. Ferreira SRS, Périco LAD, Dias VRG. The complexity of the work of nurses in Primary Health Care. Rev Bras Enferm. 2018;71( Suppl 1):704-9. doi: https:// doi.org/10.1590/0034-7167-2017-0471

4. Santos VCF, GerhardtTE. A mediação em saúde: espaços e ações de profissionais na rede de atenção à população rural. Saude Soc. 2015;24(4):1164-79. doi: https:// doi.org/10.1590/S0104-12902015139792

5. Burille A, Gerhardt TE, Lopes MJ, Dantas GC. Subjetividades de homens rurais com problemas cardiovasculares: cuidado, ameaças e afirmações da masculinidade. Saude Soc. 2018;27(2):435-47. doi: https://doi.org/10.1590/ S0104-12902018162943

6. Allieu A, Ocampo A, Rossi NW. Removing barriers to access social protection in rural areas: a core priority to achieve Sustainable Development Goal 1.3. Policy Focus. 2019 [cited 2020 May 10];16(1):39-41. Available from: https://ipcig.org/ pub/eng/PIF44_Rural_poverty_reduction_in_the_21st_century.pdf

7. Ministério da Saúde (BR). Secretaria de Gestão Estratégica e Participativa. Departamento de Apoio à Gestão Participativa. Política nacional de saúde integral das populações do campo e da floresta. Brasília: Ministério da Saúde; 2013 [cited 2020 May 15]. Available from: https://bvsms.saude.gov.br/bvs/publicacoes/ politica_nacional_saude_populacoes_campo.pdf

8. Mendes EV. Interview: The chronic conditions approach by the Unified Health System. Ciênc Saúde coletiva. 2018;23(2):431-6. doi: https://doi. org/10.1590/1413-81232018232.16152017

9. Hansen J, Groenewegen PP, Boerma WG, Kringos DS. Living in a country with a strong Primary Care System is beneficial to people with chronic conditions. Health Aff (Millwood) 2015;34(9):1531-7. doi: https://doi.org/10.1377/ hlthaff.2015.0582

10. Ministério da Saúde (BR). Portaria nº 2.436, de 21 de setembro de 2017. Aprova a Política Nacional de Atenção Básica, estabelecendo a revisão de diretrizes para a organização da Atenção Básica, no âmbito do Sistema Único de Saúde (SUS). Diário Oficial da União. 2017 set 22 [cited 2020 Jun 10];154(183 Seção 1):6876. Available from: https://pesquisa.in.gov.br/imprensa/jsp/visualiza/index. jsp?data $=22 / 09 / 2017 \&$ jornal $=1 \&$ pagina $=68 \&$ totalArquivos $=120$
11. Padilha RDQ, Gomes R, Lima VV, Soeiro E, Oliveira JMD, Schiesari LMC, et al. Principles of clinical management: connecting management, healthcare and education in health. Ciênc Saúde Coletiva. 2018;23(12):4249-57. doi: https:// doi.org/10.1590/1413-812320182312.32262016

12. Francisco PMSB, Segri NJ, Borim FSA, Malta DC. Prevalence of concomitant hypertension and diabetes in Brazilian older adults: individual and contextual inequalities. Ciênc Saúde Coletiva. 2018;23(11):3829-40. doi: https://doi. org/10.1590/1413-812320182311.29662016

13. Ministério da Saúde (BR). Secretaria de Vigilância em Saúde. Departamento de Análise em Saúde e Vigilância de Doenças Não Transmissíveis. Vigitel Brasil 2018: vigilância de fatores de risco e proteção para doenças crônicas por inquérito telefônico: estimativas sobre frequência e distribuição sociodemográfica de fatores de risco e proteção para doenças crônicas nas capitais dos 26 estados brasileiros e no Distrito Federal em 2018. Brasília (DF): Ministério da Saúde; 2019 [cited 2020 Aug 04]. Available from: https://portalarquivos2.saude.gov.br/images/pdf/2019/ julho/25/vigitel-brasil-2018.pdf

14. Canesqui AM. Legitimidade e não legitimidade das experiências dos sofrimentos e adoecimentos de longa duração. Ciênc Saúde Coletiva. 2018;23(2):409-16. doi: https://doi.org/10.1590/1413-81232018232.14732017

15. Pitilin E, Lentsck M. Primary Health Care from the perception of women living in a rural area. Rev Esc Enferm USP. 2015;49(5):726-32. doi: https://doi.org/10.1590/ S0080-623420150000500003

16. Pessoa VM, Almeida MM, Carneiro FF. Como garantir o direito à saúde para as populações do campo, da floresta e das águas no Brasil? Saúde Debate. 2018;42(spe 1):302-14. doi: https://doi.org/10.1590/0103-110420185120

17. Minayo MCS. 0 desafio do conhecimento: pesquisa qualitativa em saúde. 14. ed. São Paulo: Hucitec; 2014.

18. Mesquita MO, Riquinho DL, GerhardtTE, Ruiz ENF, organizadoras. Saúde coletiva, desenvolvimento e (in)sustentabilidades no rural. Porto Alegre: Ed. UFRGS; 2018 [cited 2020 Aug 04]. Available from: https://lume.ufrgs.br/bitstream/ handle/10183/183081/001078008.pdf?sequence=1\&isAllowed=y

19. Gomes R, Lima VV, Oliveira JMD, Schiesari LMC, Soeiro E, Damázio LF, et al. The polisemy of clinical governance: a review of literature. Ciênc Saúde Coletiva. 2018;20(8):2431-9. doi: https://doi.org/10.1590/1413-81232015208.11492014

20. Lima ARA, González JS, Ruiz MCS, Heck RM. Nursing interfaces in rural care: an integrative review. Texto Contexto Enferm. 2020;29:e20180426. doi: https://doi. org/10.1590/1980-265X-TCE-2018-0426 


\section{- Acknowledgements:}

We would like to thank the Fundação de Amparo

à Pesquisa do Rio Grande do Sul (Fapergs) for

the financial support, in partnership with the

Ministry of Health (MS), the Conselho Nacional de Desenvolvimento Científico e Tecnológico (CNPQ) do Brasil and the State Department of Health of Rio Grande do Sul (SES-RSO, within the framework of the "Programa de Pesquisa para o SUS: gestão compartilhada em saúde", notice Fapergs/MS/CNPq/ SESRS No.002/2013.

\section{- Authorship contribution:}

Adriana Roese Ramos, Deise Lisboa Rinho, and Vilma C. F. dos Santos contributed to all stages of the construction of this article, from the conceptualization of the research project to revision and editing of the paper.

Felipe R. G. de Souza e Tamires V. A. Diehl contributed to the original draft, review, and editing.

\section{- Corresponding author:}

Vilma C. F. dos Santos

Email:vilmacfsantos@gmail.com

\section{Associate editor:}

Carlise Rigon Dalla Nora 